\title{
Concordance between European and US case definitions of healthcare-associated infections
}

\author{
Sonja Hansen ${ }^{1 *}$, Dorit Sohr ${ }^{1}$, Christine Geffers ${ }^{1}$, Pascal Astagneau ${ }^{2}$, Alexander Blacky ${ }^{3}$, Walter Koller ${ }^{3}$, \\ Ingrid Morales ${ }^{4}$, Maria Luisa Moro ${ }^{5}$, Mercedes Palomar $^{6}$, Emese Szilagyi $^{7}$, Carl Suetens ${ }^{8}$ and Petra Gastmeier ${ }^{1}$
}

\begin{abstract}
Background: Surveillance of healthcare-associated infections (HAl) is a valuable measure to decrease infection rates. Across Europe, inter-country comparisons of HAI rates seem limited because some countries use US definitions from the US Centers for Disease Control and Prevention (CDC/NHSN) while other countries use European definitions from the Hospitals in Europe Link for Infection Control through Surveillance (HELICS/IPSE) project. In this study, we analyzed the concordance between US and European definitions of HAI.

Methods: An international working group of experts from seven European countries was set up to identify differences between US and European definitions and then conduct surveillance using both sets of definitions during a three-month period (March $1^{\text {st }}$-May $31^{\text {st }}, 2010$ ). Concordance between case definitions was estimated with Cohen's kappa statistic (K).

Results: Differences in HAI definitions were found for bloodstream infection (BSI), pneumonia (PN), urinary tract infection (UTI) and the two key terms "intensive care unit (ICU)-acquired infection" and "mechanical ventilation". Concordance was analyzed for these definitions and key terms with the exception of UTI. Surveillance was performed in 47 ICUs and 6,506 patients were assessed. One hundred and eighty PN and 123 BSI cases were identified. When all PN cases were considered, concordance for PN was $\mathrm{K}=0.99$ [CI 95\%: 0.98-1.00]. When PN cases were divided into subgroups, concordance was $\mathrm{K}=0.90$ (Cl 95\%: 0.86-0.94) for clinically defined PN and $\mathrm{K}=0.72$ (CI 95\%: 0.63-0.82) for microbiologically defined PN. Concordance for BSI was K=0.73 [Cl 95\%: 0.66-0.80]. However, $\mathrm{BSI}$ cases secondary to another infection site (42\% of all BSI cases) are excluded when using US definitions and concordance for BSI was $\mathrm{K}=1.00$ when only primary BSI cases, i.e. Europe-defined BSI with "catheter" or "unknown" origin and US-defined laboratory-confirmed BSI (LCBI), were considered.
\end{abstract}

Conclusions: Our study showed an excellent concordance between US and European definitions of PN and primary BSI. PN and primary BSI rates of countries using either US or European definitions can be compared if the points highlighted in this study are taken into account.

Keywords: Bloodstream infection, Pneumonia, Definitions, Healthcare-associated infections

\section{Background}

Implementation of surveillance of healthcare-associated infections (HAI) has been shown to result in decreasing HAI rates and contributes to the prevention of HAI [1-3]. Feedback of data on HAI rates to clinical staff has been shown to be a key factor reducing these rates [4-6].

\footnotetext{
* Correspondence: sonja.hansen@charite.de

${ }^{1}$ Institute for Hygiene and Environmental Medicine, Charité - University Medicine Berlin, Campus Benjamin Franklin, Hindenburgdamm 27, D-12203, Berlin, Germany

Full list of author information is available at the end of the article
}

Comparing HAI rates of one's own institution with reference data seems to be particularly successful. In the 1970s, the US Centers for Disease Control and Prevention (CDC) created the National Nosocomial Infection Surveillance System (NNIS) and published uniform surveillance definitions for nosocomial infections [7-9]. These definitions have been updated gradually for surgical site infection (SSI) [10], for ventilator-associated pneumonia (VAP) [11], primary bloodstream infection (BSI) [12] and in 2010 for urinary tract infection (UTI) [13]. Key terms such as "device-associated infection" or "intensive care unit

\section{Biomed Central}

(c) 2012 Hansen et al.; licensee BioMed Central Ltd. This is an Open Access article distributed under the terms of the Creative Commons Attribution License (http://creativecommons.org/licenses/by/2.0), which permits unrestricted use, distribution, and reproduction in any medium, provided the original work is properly cited. 
(ICU)-associated infection" were also defined [14]. This system is now integrated as part of the National Healthcare Safety Network (NHSN) [12].

In the 1980s and 1990s, many European countries performed national prevalence studies of HAI and established national surveillance systems using CDC definitions or a modified version of these definitions [15], while other countries developed their own surveillance definitions that better reflected European diagnostic practices. The first harmonization of national surveillance activities in Europe was performed by the Hospitals in Europe Link for Infection Control through Surveillance (HELICS) project, which was funded by the European Commission in the context of Decision 2119/98/EC of the European Parliament and of the Council on communicable disease surveillance and control in EU Member States [16].

The HELICS project (2000-2004) developed case definitions for surgical site infection (SSI), pneumonia $(\mathrm{PN})$, bloodstream infection (BSI), catheter-related infection (CRI) and urinary tract infection (UTI) and recommended their use in EU Member States [17,18]. The work of HELICS was continued as a component of the European Commission-funded Improving Patient Safety in Europe (IPSE) network (2005-2008). The IPSE network aimed at contributing to European surveillance of HAI by describing HAI epidemiology, improving the understanding of inter-country variation of HAI rates and facilitating quality-of-care improvements in a multicentre setting. In July 2008, the IPSE network was transferred to the European Centre for Disease Prevention and Control (ECDC) [19,20]. Since this date, HAI surveillance activities in Europe are coordinated by ECDC and the network was re-named the HealthcareAssociated Infections surveillance Network (HAI-Net). HAI-Net adopted the European (HELICS/IPSE) definitions for its HAI surveillance modules and for the ECDC point prevalence survey of HAI in European acute care hospitals. Comparisons of HAI rates between countries are essential to raising awareness about HAI and their prevention and control, but require a standardized methodology, including uniform definitions. Because they were implemented independently, national HAI surveillance systems in European countries decided to use either the US (CDC/NHSN) definitions [12-14] or the European (HELICS/IPSE) definitions $[17,18]$ and questions have been raised about whether comparisons of HAI rates between national networks were indeed appropriate. While adoption of the European definitions is mandatory for newly implemented national HAI surveillance systems, changing definitions could interrupt continuity of reference data and require reorganization for an existing national surveillance system.
The present study was conducted to assess the concordance between US (CDC/NHSN) definitions and European (HELICS/IPSE) definitions of HAI for inter-country comparison of HAI rates. The study was initiated and sponsored by ECDC through a specific service contract (ECD.1781) with the Institute for Hygiene and Environmental Medicine, Charité - University Medicine Berlin, Germany.

\section{Methods}

\section{Setting}

The study was conducted in seven European countries (Austria, Belgium, France, Germany, Hungary, Italy and Spain) with existing networks for HAI surveillance. Network leaders and a senior expert from ECDC (CS) represented the international study working group responsible for the development and implementation of the study. Three meetings at the Institute of Hygiene, Charité University Medicine, Berlin, were held to agree on the methodology, data collection and analysis.

A one-month study pre-test was performed in two countries to evaluate the feasibility of the study.

\section{Surveillance}

HAI surveillance was performed in intensive care units (ICUs) in all participating countries between March $1^{\text {st }}$ and May $31^{\text {st }}, 2010$. Network leaders delivered study documents and trained the local surveillance personnel for both types of definitions by using standardized case studies. No validation phase was included in the study.

All patients aged one year or above that presented with symptoms for selected HAI were included in surveillance according to both types of definitions. The HAI did not necessarily need to be acquired in the participating ICU, and patients coming from another ward of the same hospital with symptoms of infection were also surveyed upon ICU admission.

Local surveillance personnel collected data by using both types of definitions simultaneously. A study case was defined as a patient with a HAI according to either type of definition. In addition to the definitions' criteria, the following data were obtained for further analysis: date of birth, date of admission to the ICU and to the hospital, date of onset of HAI, underlying cardiac or pulmonary diseases, and immunosuppression status. In addition, surveillance personnel assessed whether the infection was ICUacquired, according to both sets of criteria. Association with a central line or with mechanical ventilation was also included according to the US and the European definitions. BSI cases that did not fulfill the criteria of US definitions for laboratory-confirmed bloodstream infection (LCBI) because signs and symptoms were related to an infection at another site, were recorded as "secondary BSI missed by US definitions". 


\section{Statistical analysis}

Because the question remains open as to which set of definitions represents the gold standard, we could only assess, for each type of infection, the concordance (agreement) between the two types of definitions. To estimate the concordance between two case definitions, Cohen's kappa ( $k$ ) statistic [21,22] was chosen.

For sample size calculation, an incidence of HAI (BSI and $\mathrm{PN}$ ) of $1-5$ per 100 patients was assumed and a kappa value of $0.75-0.90$ was anticipated according to previous HAI concordance studies [23-26]. Based on a kappa value of 0.75 and on an expected HAI incidence of $1 \%$, we estimated a sample size of 98 cases per infection type.

\section{Results}

\section{Differences in definitions}

Both sets of definitions of HAI were reviewed by the working group. The group identified differences for the definitions of BSI, PN and UTI (Table 1).

BSI definitions varied since CDC/NHSN does not accept a positive blood culture with a microorganism related to an infection at another site. PN definitions were different concerning the microbiological diagnostic criteria: HELICS/IPSE includes more detailed categories according to the sampling procedure and the microbiology technique whereas CDC/NHSN definitions include additional age-dependent criteria and a specific subcategory for immunocompromised patients (PNU3). UTI definitions were identical until the end of 2009. Differences appeared when CDC/NHSN modified its UTI definitions to include the new subcategory "asymptomatic bacteremic UTI" in January 2010.

Definitions of the key term "ICU-acquired infection" varied because HELICS/IPSE defines it as an infection occurring later than 48 hours after admission to an ICU, whereas $\mathrm{CDC} / \mathrm{NHSN}$ requires that there is no evidence that the infection was present or incubating at the time of admission to the ICU, without time restriction [12]. There were also differences for the key term "mechanical ventilation", which are described in Table 1 .

The working group agreed to analyze concordance for the definitions of BSI and PN, and for the key terms "ICU-acquired infection" and "mechanical ventilation".

Table 1 Differences in HAl definitions (CDC/NHSN vs. HELICS/IPSE)

\begin{tabular}{|c|c|c|}
\hline Type of HAI or key term & CDC/NHSN definitions & HELICS/IPSE definitions \\
\hline $\begin{array}{l}\text { Bloodstream infection (BSI) / } \\
\text { Laboratory-confirmed } \\
\text { bloodstream Infection (LCBI) }\end{array}$ & $\begin{array}{l}\cdot \mathrm{LCBI} \text { (Positive blood culture with recognized pathogen } \\
\text { or } 2 \text { blood cultures with skin contaminant incl. clinical } \\
\text { symptoms. Organism cultured from blood is not related } \\
\text { to an infection at another site) } \\
\text {-CSEP (Clinical sepsis in patients } \leq 1 \text { year) }\end{array}$ & $\begin{array}{l}\text { •BSI-A } \\
\text { (Positive blood culture with recognized pathogen or } \\
2 \text { blood culture with skin contaminant incl. clinical } \\
\text { symptoms. Origin: "Catheter" (C), "Secondary to } \\
\text { another site" (S) or "Unknown" (U)) }\end{array}$ \\
\hline Catheter-related infection (CRI) & $-*$ & $\begin{array}{l}\text {-CRI } 1 \text { (Local central venous catheter } \\
\text { (CVC)-related infection) } \\
\text { •CRI } 2 \text { (General CVC-related infection) } \\
\text { - CRI } 3 \text { (CVC-related BSI) } \\
\text { - CCO (Catheter colonisation) }\end{array}$ \\
\hline Pneumonia (PNU/PN) & $\begin{array}{l}\text { - PNU1 (Clinically defined pneumonia) } \\
\text { - PNU2 (Pneumonia with specific laboratory findings) } \\
\text { - PNU3 (Pneumonia in immunocompromised patients) }\end{array}$ & $\begin{array}{l}\text { - PN } 1 \text { (Protected sample + quantitative culture) } \\
\text { - PN } 2 \text { (Non-protected sample + quantitative culture) } \\
\text { - PN } 3 \text { (Alternative microbiological criteria) } \\
\text { - PN } 4 \text { (Sputum bacteriology or non-quantitative } \\
\text { endotracheal aspirate (ETA)) } \\
\text { - PN } 5 \text { (No microbiological criterion (only clinical criteria)) }\end{array}$ \\
\hline Urinary tract infection (UTI) & $\begin{array}{l}\cdot \text { SUTI (Symptomatic UTI) }+/ \neq \\
\cdot \text { ASB (Asymptomatic bacteriuria) }+/ \\
\text {-ABUTI (Asymptomatic bacteremic UTI) } \neq \\
\text { - OUTI (Other infections of the urinary tract) }+/ \neq\end{array}$ & $\begin{array}{l}\text { - UTI-B (Symptomatic, not microbiologically confirmed) } \\
\text { • UTI-C (Asymptomatic bacteriuria) }\end{array}$ \\
\hline ICU-acquired HAI & $\begin{array}{l}\text { - No evidence that the infection was present or } \\
\text { incubating at the time of admission to the ICU }\end{array}$ & $\begin{array}{l}\text { - Infection occurred later than } 48 \text { hours after admission } \\
\text { in the ICU }\end{array}$ \\
\hline Ventilator-associated & $\begin{array}{l}\text { - A device to assist or control respiration continuously } \\
\text { through a tracheostomy or by endotracheal intubation } \\
\text { was present within the } 48 \text {-hour period before the } \\
\text { onset of infection, inclusive of the weaning period }\end{array}$ & $\begin{array}{l}\text { - An invasive respiratory device was present } \\
\text { (even intermittently) in the } 48 \text { hours preceding the } \\
\text { onset of infection }\end{array}$ \\
\hline
\end{tabular}

*, not applicable.

†, until December 2008.

$\neq$, since January 2009. 
Since US and European definitions of UTI showed major differences because of recent modifications, UTI definitions were excluded from the study.

\section{Participating ICUs}

Surveillance was performed in 47 ICUs in 28 hospitals across 7 EU countries. The majority of participating ICUs were mixed ICUs, followed by medical and surgical ICUs. Three countries also surveyed paediatric patients in $9 \%$ of their participating ICUs. The characteristics of participating ICUs are presented in Table 2.

\section{Agreement of definitions}

For the study, 6,506 patients were assessed. The incidence of PN and of BSI were 2.8 and 1.9 per 100 patients, respectively. Overall, $180 \mathrm{PN}$ and 123 BSI cases were identified by either the US definitions or the European definitions (Figures 1 and 2). Of all 180 PN cases, 178 were identified with the European definitions and 179 with the US definitions. Two PN cases were only identified with the US definitions due to age-dependent criteria that are not included in the European definitions. The third discordant case was a patient with microbiological findings that fulfilled a criterion for "PN 2" of the European definitions, but without sufficient criteria for PN according to the US definitions. These findings led to a kappa value of 0.99 for PN. Kappa values were lower when PN cases were subdivided into clinically defined PN $(\kappa=0.90)$ and microbiologically defined PN $(\kappa=0.72)$.

Since this subdivision did not take into account US-defined PNU3 cases (PN in immunocompromised patients), those cases were reclassified into US-defined PNU1 and PNU2. A repeated analysis of agreement within the new clinically and microbiologically defined $\mathrm{PN}$ groups resulted in equal agreement for clinically defined PN $(K=0.90)$ and higher agreement for microbiologically defined PN $(\kappa=0.84)$.
Agreement of definitions for BSI showed a kappa value of 0.73 . All 123 BSI cases were diagnosed by the European criteria. Forty-two percent of the BSI cases were missed when US definitions were used (Figure 2) because they were secondary to an infection at another site. In the remaining 72 cases, the BSI origin was either a catheter (central venous, peripheral or arterial) (30\%) or unknown (29\%). BSI concordance was perfect $(\kappa=1.00)$ when only primary BSI cases, i.e. Europe-defined BSI with either "catheter" or "unknown" origin and US-defined "LCBI", were analyzed.

For 245 (81\%) of all cases the concordance of the key term "ICU-acquired" was analyzed. A few more HAI were classified as "ICU-acquired" according to the US definitions than to the European definitions (245 vs. 240); agreement was equal for ICU-acquired $\mathrm{PN}$ and for ICU-acquired BSI $(\kappa=0.94)$ (Table 3$)$.

\section{Discussion}

HAI surveillance methods vary across Europe. Some countries use European definitions while other countries use US definitions. As a contribution to further harmonization of Europe-wide surveillance of HAI, this study assessed the concordance between US and European definitions of BSI and of PN, two major types of HAI that are partly preventable [27] and are under surveillance in most European countries. The recommendations of Landis and Koch for evaluating the strength of an agreement were used [28]. Overall, an "almost perfect" agreement was found for PN ( $\mathrm{K}=0.99)$. This was different when PN cases were subdivided into clinically and microbiologically defined PN. More PN cases were classified as microbiologically-defined PN following the European definitions than the US definitions. This was still the case when Europe-defined PN2 cases which are based on the criteria "non-protective sample and quantitative culture" were considered as clinically defined PN. This difference was no longer evident when all

Table 2 Participating intensive care units (ICUs)

\begin{tabular}{|c|c|c|c|c|c|c|c|c|c|c|}
\hline \multirow[t]{2}{*}{ Country } & \multirow{2}{*}{$\begin{array}{l}\text { Number of } \\
\text { ICUs / Number } \\
\text { of hospitals }\end{array}$} & \multicolumn{5}{|c|}{ Number of ICUs per specialty* } & \multirow{2}{*}{$\begin{array}{l}\text { Median number of } \\
\text { beds per hospital }\end{array}$} & \multirow{2}{*}{$\begin{array}{l}\text { Median number } \\
\text { of beds per ICU }\end{array}$} & \multirow{2}{*}{$\begin{array}{l}\text { Median number } \\
\text { of beds with a } \\
\text { ventilator } \\
\text { per ICU (n) }\end{array}$} & \multirow{2}{*}{$\begin{array}{c}\text { Number of } \\
\text { included } \\
\text { patients }\end{array}$} \\
\hline & & Mixed & $\begin{array}{l}\text { Internal } \\
\text { medicine }\end{array}$ & Surgery & $\begin{array}{l}\text { Cardiac } \\
\text { surgery }\end{array}$ & Othert & & & & \\
\hline Austria & $7 / 1$ & 3 & 3 & 0 & 0 & 1 & 2,137 & 8 & 8 & 132 \\
\hline Belgium & $5 / 4$ & 3 & 1 & 1 & 0 & 0 & 854 & 18 & 18 & 1,318 \\
\hline France & $4 / 4$ & 2 & 0 & 2 & 0 & 0 & 504 & 11 & 11 & 323 \\
\hline Germany & $5 / 1$ & 2 & 0 & 0 & 1 & 2 & 3,200 & 11 & 11 & 689 \\
\hline Hungary & $15 / 10$ & 7 & 1 & 2 & 2 & 3 & 1,163 & 10 & 10 & 2,311 \\
\hline Italy & $7 / 4$ & 2 & 1 & 2 & 0 & 2 & 474 & 8 & 8 & 1,031 \\
\hline Spain & $4 / 4$ & 3 & 0 & 0 & 0 & 1 & 600 & 19 & 16 & 702 \\
\hline All & $47 / 28$ & 22 & 6 & 7 & 3 & 9 & 854 & 11 & 11 & 6,506 \\
\hline
\end{tabular}

* An ICU was defined as belonging to a specialty if $\geq 80 \%$ of patients in this ICU belonged to this specialty.

† Other: Neurosurgery, Paediatrics, Transplant surgery, Burn, Neurology. 


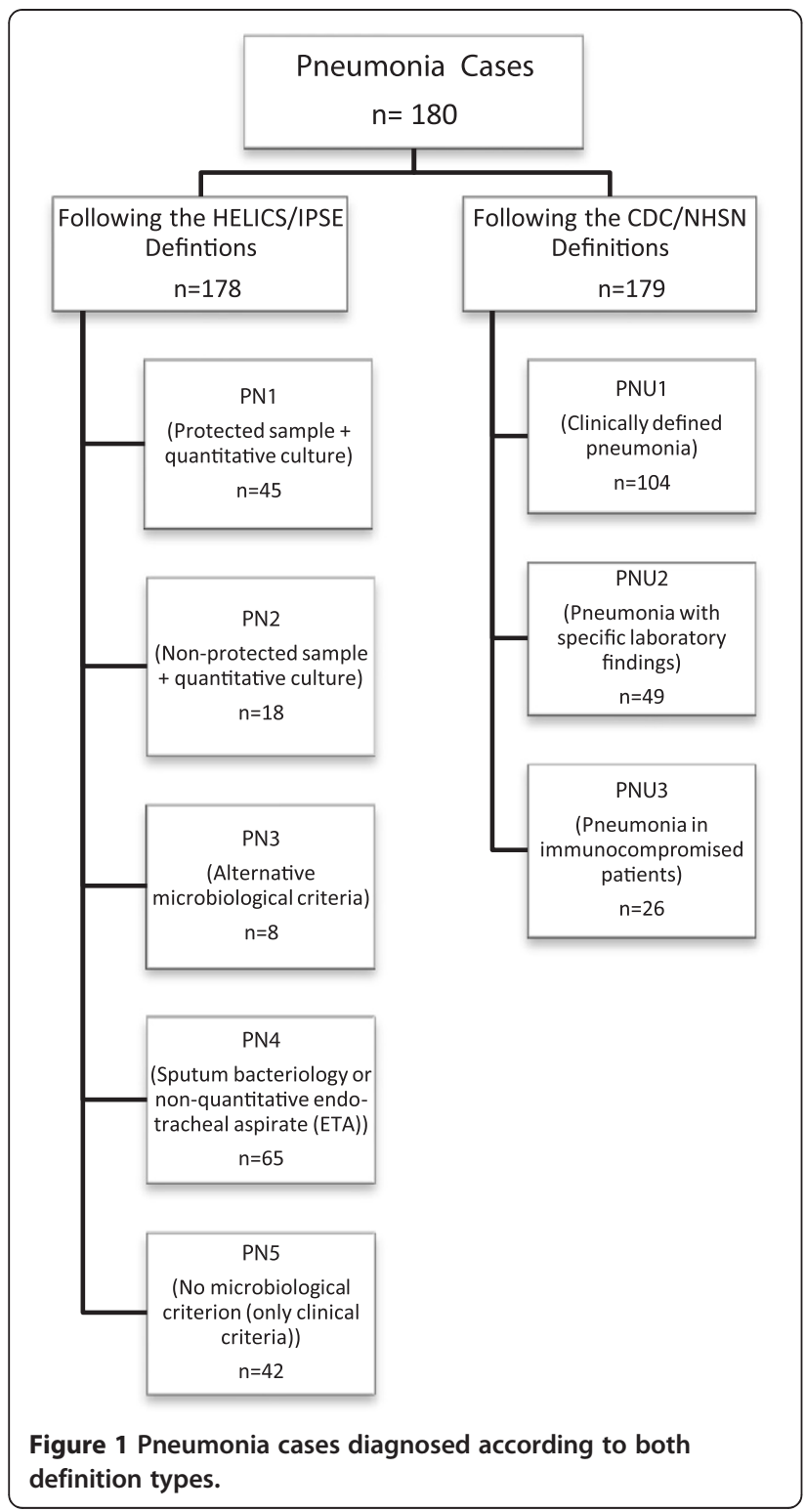

US-defined PNU3 ("PN in immunocompromised patients") cases were reclassified into the US-defined categories PNU1 or PNU2. Since all 26 PNU3 cases could be classified as either PNU1 cases $(n=2)$ or PNU2 cases $(n=24)$, the results of this study suggest that the PNU3 subcategory may not be essential when performing surveillance of PN in immunocompromised patients.

As expected, concordance of BSI definitions was only "substantial" according to Landis and Koch [28]. Since one major criterion of US definitions, i.e. signs and symptoms of BSI must not be related to an infection at another site, is not included in the European definitions, $51(42 \%)$ BSI cases were not identified with the US definition. With the European BSI definition, which includes the specification of the origin of the BSI, these

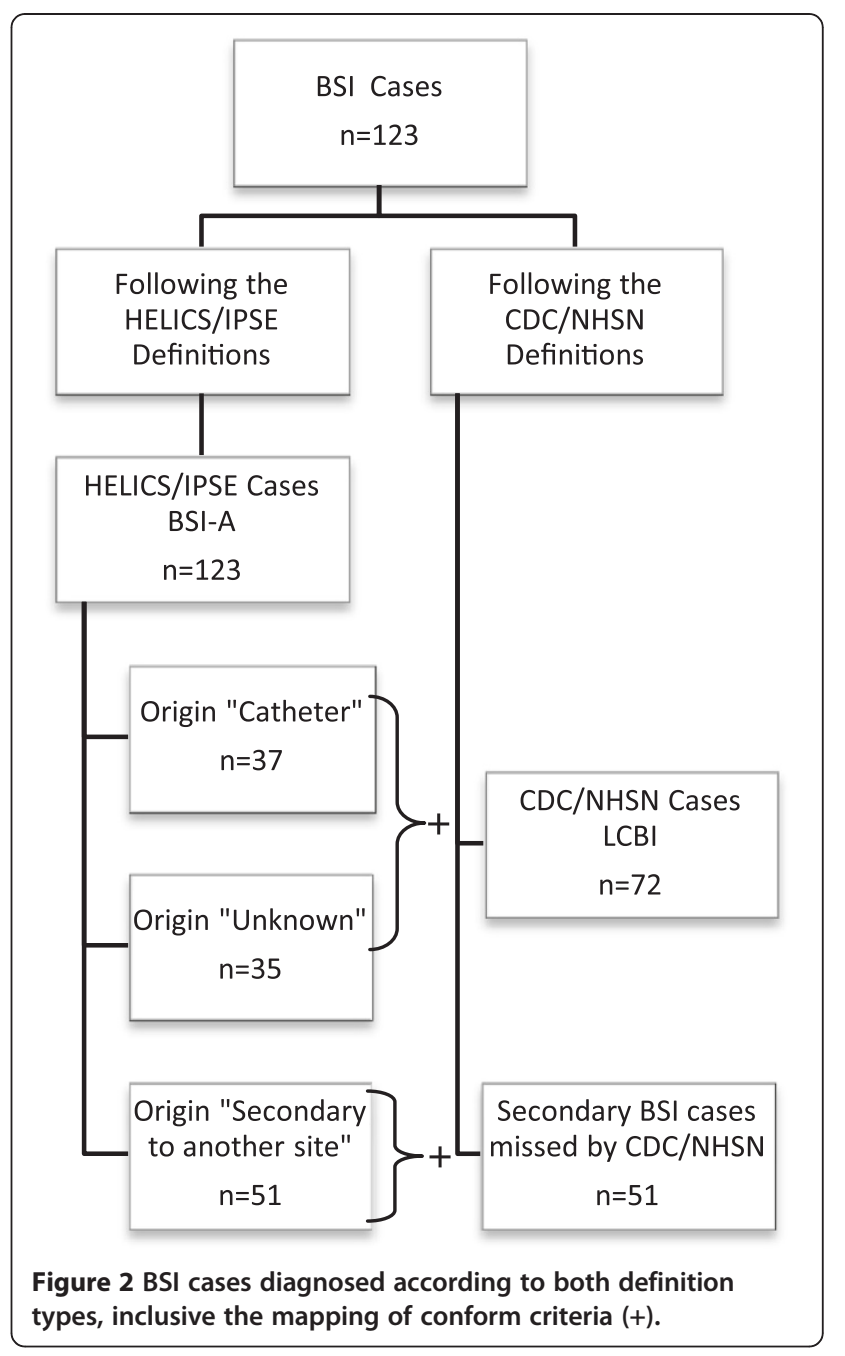

51 BSI cases were reported as "secondary to another infection site".

European definitions provide two more categories, i.e. "catheter" and "unknown", for origin of BSI [18]. The origin "catheter" was reported in 37 (30\%) BSI cases and the origin "unknown" was reported in 35 (29\%) BSI cases, which correspond to the "primary BSI" of the US definitions. All 72 of these BSI cases were also defined as LCBI cases with the US definitions. Thus for a potential comparison, US-defined LCBI cases should only be related to Europe-defined BSI cases with either "catheter" or "unknown" origin.

Definitions of the key term "ICU-acquired HAI" varied between the U.S. and Europe. According to European definitions $97 \%$ of HAI cases were defined as ICUacquired (i.e. HAI occurring later than 48 hours after admission in the ICU). By contrast, according to the US definitions, all HAI cases were defined as ICU-acquired (i.e., no evidence that the infection was present or incubating at the time of admission to the ICU). Since US 
Table 3 Concordance of HAl definitions, determined by Cohen's kappa statistic

\begin{tabular}{|c|c|c|c|c|c|c|c|c|c|}
\hline \multirow{2}{*}{$\begin{array}{l}\text { Type of HAI } \\
\text { or key term }\end{array}$} & \multicolumn{2}{|c|}{ Included cases based on: } & \multirow{2}{*}{$\begin{array}{c}\text { Incidence of } \\
\text { HAI (no. cases } \\
\text { per } 100 \text { patients) }\end{array}$} & \multicolumn{4}{|c|}{ No. cases of $\mathrm{HAl}$} & \multirow{2}{*}{$\begin{array}{l}\text { No. patients } \\
\text { without HAI }\end{array}$} & \multirow{2}{*}{$\begin{array}{c}\text { Cohen's kappa } \\
\text { [95\% confidence } \\
\text { interval] }\end{array}$} \\
\hline & US definitions & $\begin{array}{l}\text { European } \\
\text { definitions }\end{array}$ & & $\begin{array}{l}\text { According to } \\
\text { either the } \\
\text { European or the } \\
\text { US definition }\end{array}$ & $\begin{array}{l}\text { According to both } \\
\text { the European and } \\
\text { the US definitions }\end{array}$ & $\begin{array}{l}\text { According to } \\
\text { the European } \\
\text { definition but } \\
\text { not the US } \\
\text { definition }\end{array}$ & $\begin{array}{l}\text { According to the } \\
\text { US definition } \\
\text { but not the } \\
\text { European } \\
\text { definition }\end{array}$ & & \\
\hline Pneumonia & PNU1 + PNU2 + PNU3 & $\begin{array}{c}\mathrm{PN} 1+\mathrm{PN} 2+\mathrm{PN} 3+ \\
\text { PN4 + PN5 }\end{array}$ & 2.8 & 180 & 177 & 1 & 2 & 6,326 & $0.99[0.98 ; 1.00]$ \\
\hline \multirow{4}{*}{$\begin{array}{l}\text { Clinically defined } \\
\text { pneumonia }\end{array}$} & PNU1 & $\mathrm{PN} 2+\mathrm{PN} 4+\mathrm{PN} 5$ & 2.0 & 127 & 102 & 23 & 2 & 6,379 & $0.89[0.85 ; 0.93]$ \\
\hline & PNU1 & PN4 + PN5 & 1.8 & 119 & 92 & 15 & 12 & 6,387 & $0.87[0.82 ; 0.92]$ \\
\hline & PNU1* & $\mathrm{PN} 2+\mathrm{PN} 4+\mathrm{PN} 5$ & 2.0 & 127 & 104 & 21 & 2 & 6,379 & $0.90[0.86 ; 0.94]$ \\
\hline & PNU1* & PN4 + PN5 & 1.8 & 119 & 94 & 13 & 12 & 6,387 & $0.88[0.83 ; 0.93]$ \\
\hline \multirow{4}{*}{$\begin{array}{l}\text { Microbiologically } \\
\text { defined pneumonia }\end{array}$} & PNU2 & PN1 + PN3 & 1.0 & 65 & 37 & 16 & 12 & 6,441 & $0.72[0.63 ; 0.82]$ \\
\hline & PNU2 & $P N 1+P N 2+P N 3$ & 1.2 & 78 & 42 & 29 & 7 & 6,428 & $0.70[0.60 ; 0.79]$ \\
\hline & PNU2† & PN1 + PN3 & 1.1 & 73 & 53 & 0 & 20 & 6,433 & $0.84[0.77 ; 0.91]$ \\
\hline & PNU2† & $P N 1+P N 2+P N 3$ & 1.3 & 84 & 60 & 11 & 13 & 6,422 & $0.83[0.77 ; 0,90]$ \\
\hline $\begin{array}{l}\text { ICU-acquired } \\
\text { pneumonia }\end{array}$ & $\begin{array}{c}\text { Pneumonia not present } \\
\text { or in incubation at } \\
\text { admission }\end{array}$ & $\begin{array}{l}\text { Pneumonia occurring } \\
>48 \mathrm{~h} \text { after admission }\end{array}$ & 2.3 & 147 & 144 & 0 & 3 & 28 & $0.94[0.87 ; 1.00]$ \\
\hline $\begin{array}{l}\text { Mechanical } \\
\text { ventilation }\end{array}$ & $\begin{array}{c}\text { Continuous presence } \\
\text { of device within } 48 \\
\text { hours preceding } \\
\text { pneumonia onset }\end{array}$ & $\begin{array}{l}\text { Presence of device } \\
\text { (even intermittently) } \\
\text { within } 48 \text { hours } \\
\text { preceding } \\
\text { pneumonia onset }\end{array}$ & 2.1 & 136 & 134 & 2 & 0 & 42 & $0.97[0.93 ; 1.00]$ \\
\hline $\begin{array}{l}\text { Bloodstream } \\
\text { infection (BSI) }\end{array}$ & $\begin{array}{l}\text { Microorganism is not } \\
\text { related to infection } \\
\text { at another site }\end{array}$ & $\begin{array}{l}\text { Origin of BSI is } \\
\text { "catheter", "secondary } \\
\text { to another site" } \\
\text { or "unknown" }\end{array}$ & 1.9 & 123 & 72 & 51 & 0 & 6,383 & $0.73[0.66 ; 0.80]$ \\
\hline Primary BSI & $\begin{array}{l}\text { Microorganism is not } \\
\text { related to infection } \\
\text { at another site }\end{array}$ & $\begin{array}{l}\text { Origin of BSI is } \\
\text { "catheter" or } \\
\text { "unknown" }\end{array}$ & 1.1 & 72 & 72 & 0 & 0 & 51 & 1.00 \\
\hline ICU-acquired BSI & $\begin{array}{l}\text { BSI not present or } \\
\text { in incubation at } \\
\text { admission }\end{array}$ & $\begin{array}{l}\text { BSI occurring }>48 \mathrm{~h} \\
\text { after admission }\end{array}$ & 1.5 & 98 & 96 & 0 & 2 & 22 & $0.94[0.87 ; 1.00]$ \\
\hline
\end{tabular}

*Including PNU3 cases (pneumonia in the immunocompromised patient) qualified as PNU1 after redistribution of PNU3 cases into PNU1 or PNU2.

+ Including PNU3 cases (pneumonia in the immunocompromised patient) qualified as PNU2 after redistribution of PNU3 cases into PNU1 or PNU2. 
definitions do not specify a time period between admission to the ICU and onset of symptoms, it is easy to explain why a few more HAI were recorded as ICU-acquired according to the US definitions. Nevertheless, agreement for the key term "ICU-acquired HAI" was still "almost perfect" according to Landis and Koch [28].

A strength of our study is that it was performed in seven European countries with different diagnostic methods and habits reflecting the variety of diagnostic practices in Europe. A limitation of the study is that the time of admission to the ICU and the time of onset of the HAI were recorded less precisely (in "days" instead of "hours") than in the original definition because the findings of the study pre-test revealed major difficulties in collecting time of onset data in "hours". As a consequence, all HAI occurring on or after the third day of ICU stay (rather than after 48 hours according to the European definitions), were defined as ICU-acquired. A further limitation was that specific patient groups, such as paediatric and immunocompromised patients, were likely to be underrepresented in the study.

In conclusion, countries using either US or European definitions for HAI surveillance can compare PN and primary BSI rates as long as the following points are taken into account. First, data should of course be valid and be collected following the original US and European definitions since country-specific modification of definitions may result in additional differences [29]. Second, PN data should always be compared in total, but not as subcategories of clinically defined and microbiologically defined PN. Third, for BSI the source should always be reported since all BSI cases with the origin "secondary to another site" according to European definitions should be excluded when making comparisons with US-defined BSI. Fourth, only Europe-defined BSI cases with either "catheter" or "unknown" origin should be compared to US-defined LCBI cases. Fifth, there are differences between US and European surveillance protocols, other than just case definitions of HAI, and these differences should be taken into account before performing comparison of HAI rates. Finally, comparisons are valid as long as US and European definitions do not change. Indeed, changing US definitions for PN to ventilator-associated complications under the influence of public reporting $[30,31]$ would certainly affect the current good concordance between US and European definitions of PN.

\section{Abbreviations}

BSI: Bloodstream infection; CDC: Centers for disease control and prevention; ECDC: European Centre For Disease Prevention And Control; HAl: Healthcareassociated infection; HELICS: Hospitals in Europe Link for Infection Control through Surveillance; ICU: Intensive care unit; IPSE: Improving patient safety in Europe; k: Kappa; LCBI: Laboratory-confirmed bloodstream infection; NHSN: National Healthcare Safety Network; NNIS: System National Nosocomial Infection Surveillance System; PN: Pneumonia; PN1-5: Pneumonia case definitions (according to HELICS/IPSE); PNU1: Clinically defined pneumonia (according to CDC/NHSN); PNU2: Pneumonia with specific laboratory findings (according to CDC/NHSN); PNU3: Pneumonia in immunocompromised patients (according to CDC/NHSN); SSI: Surgical site infection; UTI: Urinary tract infection.

\section{Competing interests}

The study was supported by the European Centre for Disease Prevention and Control (ECDC) through a specific service contract (ECD.1781). The authors declare that they have no competing interests.

\section{Authors' contributions}

The study was designed by all members of the working group ( $P A, A B, P G$, SH, WK, IM, MLM, MP, ES, CS) and by CG and DS. PG was the investigator of the study. SH coordinated the study. PA, AB, SH, IM, MLM, MP, ES performed the study in their respective countries. DS performed the statistical analysis. $\mathrm{SH}$ drafted the manuscript. All authors critically revised the manuscript and contributed substantially to the submitted version. All authors have read and approved the final manuscript.

\section{Acknowledgements}

The authors would like thank Michael Behnke and Florian Schmid, Charité University Medicine Berlin, Germany, for support with data management and the following colleagues for making the surveillance data available: Belgium: Karl Mertens, Scientific Institute of Public Health, Brussels; Pieter Depuydt, Ghent University Hospital, Gent; Pierre Damas, University Hospital Liège, Liège; Jacques Devriendt, Brugmann University Hospital, Brussels; Claire Boland, Clinique Saint-Jean, Brussels.

France: Jean-Winoc Decousser, Antoine Béclère Hospital, Clamart; Xavier Becanne, Hôtel Dieu Hospital, Paris; Anne Casetta, Hôtel Dieu Hospital, Paris; Alain Combés, General Hospital, Meaux; Jacques Merrer, Gilles Troché, General Hospital, Versailles.

Germany: Nadine Mönch, Andrea Landskron, Vivien Luchtenberg, Carola Schönborn, Charité - University Medicine, Berlin.

Hungary: Márta Patyi, Bács-Kiskun County Teaching Hospital, Kecskemét; Erika Rauth, University of Pecs Clinical Center; Sára Uray, Gabriella Csók, Gyula Prinz, Hungarian Institute of Cardiology, Budapest; Irén Németh, Military Hospital, Budapest; Erzsébet Rákay, Irén Heid, Tünde Aszalay, Szent János Hospital, Budapest; Erika Hemző, Szent Imre Hospital, Budapest; Kamilla Nagy, Renata Süli, University of Szeged, Albert Szent-Györgyi Clinical Center; Piroska Orosi, University of Debrecen; Zsuzsanna Fekete, Irén Kapus, Szent Lukács Hospital, Dombóvár; Zsófia Ozsvár, Szent György Hospital, Székesfehérvár. Italy: Stefano Giordani, Massimo Girardis, Lucia Serio AUSL Modena; Maria Rita Melotti, Marco Adversi, Simonetta Baroncini AOU Bologna; Francesca Faccondini, Grazia Tura, AUSL Rimini; Veronica Cappelli, Davide Resi ASSR Emilia-Romagna.

Spain: MJ Lopez-Pueyo, Hospital Gral Yague, Burgos; Magda Campins, Hospital Vall Hebron, Barcelona; Josu Insausti, Hospital Provincial, Pamplona.

\section{Author details}

${ }^{1}$ Institute for Hygiene and Environmental Medicine, Charité - University Medicine Berlin, Campus Benjamin Franklin, Hindenburgdamm 27, D-12203, Berlin, Germany. ${ }^{2}$ C-CLIN Nord - Département de santé publique, Université Pierre \& Marie Curie, Paris, France. ${ }^{3}$ Clinical Institute for Hygiene and Medical Microbiology, Medical University of Vienna, Vienna, Austria. ${ }^{4}$ National Surveillance of Infections in Hospitals - NSIH, Operational Direction Public Health and Surveillance, Scientific Institute of Public Health, Brussels, Belgium. ${ }^{5}$ Agenzia Sanitaria e Sociale Regione Emilia Romagna, Area di Programma Rischio Infettivo, Bologna, Italy. ${ }^{6}$ Department of Intensive Care, Hospital Vall d'Hebron, Barcelona, Spain. ${ }^{7}$ National Centre for Epidemiology, Department of Hospital Epidemiology, Budapest, Hungary. ${ }^{8}$ European Centre for Disease Prevention and Control, Stockholm, Sweden.

Received: 18 March 2012 Accepted: 17 July 2012

Published: 2 August 2012

\section{References}

1. Haley RW, Culver DH, White JW, Morgan WM, Emori TG, Munn VP, Hooton TM: The efficacy of infection surveillance and control programs in preventing nosocomial infections in US hospitals. Am J Epidemiol 1985, 121:182-205.

2. Geubbels E, Bakker HG, Houtman P, Van Noort-Klaassen MA, Pelk MS, Sassen TM, Wille JC: Promoting quality through surveillance of surgical site 
infections: five prevention success stories. Am J Infect Control 2004, 32:424-430.

3. Gastmeier P, Schwab F, Sohr D, Behnke M, Geffers C: Reproducibility of the surveillance effect to decrease nosocomial infection rates. Infect Control Hosp Epidemiol 2009, 30:993-999.

4. Astagneau P, L'Hériteau F: Surveillance of surgical-site infections: impact on quality of care and reporting dilemmas. Curr Opin Infect Dis 2010, 23:306-310.

5. Gastmeier P, Sohr D, Schwab F, Behnke M, Zuschneid I, Brandt C, Dettenkofer $M$, Chaberny IF, Rüden H, Geffers C: Ten years of KISS: the most important requirements for success. J Hosp Infect 2008, 70(Suppl 1):11-16.

6. Gaynes R, Richards C, Edwards J, Emori TG, Horan T, Alonso-Echanove J, Fridkin S, Lawton R, Peavy G, Tolson J: Feeding back surveillance data to prevent hospital-acquired infections. Emerg Infect Dis 2001, 7:295-298.

7. Horan TC, White JW, Jarvis WR, Emori TG, Culver DH, Munn VP, Thornsberry C, Olson DR, Hughes JM: Nosocomial infection surveillance, 1984. MMWR CDC Surveill Summ 1986, 35:17-29.

8. Hughes JM: Nosocomial infection surveillance in the United States: historical perspective. Infect Control 1987, 8:450-453.

9. Garner JS, Jarvis WR, Emori TG, Horan TC, Hughes JM: CDC definitions for nosocomial infections, 1988. Am J Infect Control 1988, 16:128-140.

10. Horan TC, Gaynes RP, Martone WJ, Jarvis WR, Emori TG: CDC definitions of nosocomial surgical site infections, 1992: a modification of CDC definitions of surgical wound infections. Infect Control Hosp Epidemiol 1992, 13:606-608.

11. Horan T, Gaynes R: Surveillance of nosocomial infections. In Hospital Epidemiology and Infection Control. 3rd edition. Edited by Mayhall CG. Philadelphia: Lippincott Williams \&Wilkins; 2004:1659-1689.

12. Horan TC, Andrus M, Dudeck MA: CDC/NHSN surveillance definition of health care-associated infection and criteria for specific types of infections in the acute care setting. Am J Infect Control 2008, 36:309-332.

13. Gould $C$, Allen-Bridson $K$, Horan $T$ : Surveillance definitions for urinary tract infections. Clin Infect Dis 2009, 49:1288-1289.

14. Horan TC, Emori TG: Definitions of key terms used in the NNIS System. Am J Infect Control 1997, 25:112-116.

15. Gastmeier P, Kampf G, Wischnewski N, Schumacher M, Daschner F, Rüden $\mathrm{H}$ : Importance of the surveillance method: national prevalence studies on nosocomial infections and the limits of comparison. Infect Control Hosp Epidemiol 1998, 19:661-667.

16. Decision No 2119/98/EC of the European Parliament and of the Council of 24 September 1998 setting up a network for the epidemiological surveillance and control of communicable diseases in the Community; http://ec.europa.eu/ health/communicable_diseases/early_warning/comm_legislation_en.htm (accessed on 2012-03-12).

17. Suetens C, Savey A, Labeeuw J, Morales I: The ICU-HELICS programme: towards European surveillance of hospital-acquired infections in intensive care units. Euro Surveill 2002, 7:127-128.

18. Suetens C, Morales I, Savey A, Palomar M, Hiesmayr M, Lepape A, Gastmeier P, Schmit JC, Valinteliene R, Fabry J: European surveillance of ICU-acquired infections (HELICS-ICU): methods and main results. J Hosp Infect 2007, 65(Suppl 2):171-173.

19. European Centre for Disease Prevention and Control (ECDC): Annual Epidemiological Report on Communicable Diseases in Europe 2008. Stockholm: ECDC; 2008:16-38.

20. European Centre for Disease Prevention and Control (ECDC): Epidemiology of communicable diseases in Europe, 2006. In Annual Epidemiological Report on Communicable Diseases in Europe 2008. Stockholm: ECDC; 2008:289-295

21. Cohen J: A coefficient of agreement for nominal scales. Educ Psychol Meas 1960, 20:37-46.

22. Cohen J: Weighted kappa: Nominal scale agreement with provision for scaled disagreement or partial credit. Psych Bull 1968, 70:213-220.

23. Minei JP, Hawkins K, Moody B, Uchal LB, Joy K, Christensen LL, Haley RW: Alternative case definitions of ventilator associated pneumonia identify different patients in a surgical intensive care unit. Shock 2000, 14:331-337.

24. Wilson A, Gibbons C, Reeves B, Hiodgson B, Liu M, Plummer D, Krukowski $\mathrm{ZH}$, Bruce J, Wilson J, Pearson A: Surgical wound infection as a performance indicator: agreement of common definitions of wound infection in 4773 patients. BMJ 2004, 329:720.
25. Gastmeier P, Hentschel J, De Veer I, Obladen M, Rüden H: Deviceassociated nosocomial infection surveillance in neonatal intensive care using specified criteria for neonates. J Hosp Infect 1998, 38:51-60.

26. Beck K, Gastmeier P: Clinical or epidemiologic diagnosis of nosocomial pneumonia: Is there any difference? Am J Infect Control 2003, 31:331-335

27. Harbarth S, Sax H, Gastmeier P: The preventable proportion of nosocomial infections: an overview of published reports. J Hosp Infect 2003, 54:258-266.

28. Landis JR, Koch GG: The measurement of observer agreement for categorical data. Biometrics 1977, 33:159-174.

29. Hansen S, Schwab F, Behnke M, Carsauw H, Heczko P, Klavs I, Lyytikäinen O, Palomar M, Riesenfeld Orn I, Savey A, Szilagyi E, Valinteliene R, Fabry J, Gastmeier P: National influences on catheter-associated bloodstream infection rates: practices among national surveillance networks participating in the European HELICS project. J Hosp Infect 2009, 71:66-73.

30. Klompas M, Kleinman K, Khan Y, Evans RS, Lloyd JF, Stevenson K, Samore M, Platt R: CDC Prevention Epicenters Program. Rapid and reproducible surveillance for ventilator-associated pneumonia. Clin Infect Dis 2012 54:370-377.

31. Magill SS, Fridkin SK: Improving surveillance definitions for ventilatorassociated pneumonia in an era of public reporting and performance measurement. Clin Infect Dis 2012, 54:378-80.

doi:10.1186/2047-2994-1-28

Cite this article as: Hansen et al:: Concordance between European and US case definitions of healthcare-associated infections. Antimicrobial Resistance and Infection Control 2012 1:28.

\section{Submit your next manuscript to BioMed Central and take full advantage of:}

- Convenient online submission

- Thorough peer review

- No space constraints or color figure charges

- Immediate publication on acceptance

- Inclusion in PubMed, CAS, Scopus and Google Scholar

- Research which is freely available for redistribution

Submit your manuscript at www.biomedcentral.com/submit
C Biomed Central 